\title{
Heterotrophic flagellates (Amorpha and Diaphoretiches) in phytotelmata bromeliad (Bromeliaceae)
}

\author{
P. M. Sachertt Mendes ${ }^{a}$ (D), F. M. Lansac-Tôhab (D), B. R. Meira ${ }^{b}$ (D), F. R. Oliveirab (D), \\ L. F. M. Velho ${ }^{b, c}$ (iD and F. A. Lansac-Tôha ${ }^{b *}$ (i) \\ aPrograma de Pós-graduação em Biologia Comparada, Universidade Estadual de Maringá - UEM, Av. Colombo, 5790, \\ CEP 87020-900, Maringá, PR, Brasil

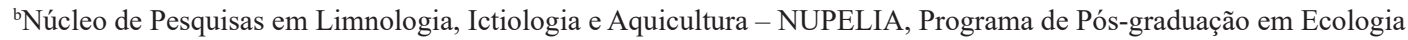 \\ de Ambientes Aquáticos Continentais, Universidade Estadual de Maringá - UEM, Av. Colombo, 5790, CEP 87020-900, \\ Maringá, PR, Brasil \\ 'Instituto Cesumar de Ciência, Tecnologia e Inovação - ICETI, Centro Universitário Cesumar - Unicesumar, Av. Guedner, \\ 1610, CEP 87050-900, Maringá, PR, Brasil \\ *e-mail: fabio@nupelia.uem.br
}

Received: 18 January 2019 - Accepted: 21 May 2019 - Distributed: August 31, 2020

(With 19 figures)

\begin{abstract}
Many plants may accumulate rainwater, forming phytotelmata, aquatic microhabitats inhabited by various organisms. The aim of this study was to conduct an inventory of heterotrophic flagellates associated with phytotelmata of the bromeliad Aechmea distichantha Lem., found in rocky cliffs on the Upper Paraná River. The bromeliads were removed manually from the rocky wall, the water was removed and cultures of organisms of each plant were mounted in Petri dishes. Sixteen species of heterotrophic flagellate were recorded, drawn and described, among them one species belonging to the Amorpha Domain and 15 species to the Diaphoretiches Domain. The groups with most species were Euglenida and Kinetoplastea. The low diversity of heterotrophic flagellates recorded in this study, compared to the plankton of lakes and reservoirs, is probably related to the fact that phytotelmata are habitats with extreme environmental conditions, thus selecting organisms tolerant to these environments.
\end{abstract}

Keywords: Aechmea distichantha, phytotelmata, protists, heterotrophic flagellates.

\section{Flagelados heterotróficos (Amorpha e Diaphoretiches) em fitotelmata de bromélia (Bromeliaceae)}

\section{Resumo}

Em sua superfície externa, muitas plantas podem acumular água da chuva formando fitotelmata, ou seja, micro-habitat aquáticos colonizados por diversos organismos, entre eles, os flagelados protistas. Fez-se um inventário de flagelados heterotróficos associados ao fitotelmata da bromélia Aechmea distichantha Lem., encontrada em paredões rochosos em um trecho da bacia do alto rio Paraná. As bromélias foram retiradas manualmente de paredão rochoso e, em laboratório, a água foi retirada dos tanques de cada planta, e foram montadas culturas dos organismos em placas de Petri. Os flagelados heterotróficos foram, então, observados in vivo sob microscópio óptico Olympus BX51, com sistema de contraste de interferência diferencial (DIC) acoplado. Dezesseis espécies flagelados heterotróficos foram registradas, desenhadas e descritas, sendo uma espécie pertencente ao Domínio Amorpha e 15 espécies ao Domínio Diaphoretiches. Os grupos mais especiosos foram Euglenida e Kinetoplastea. A diversidade relativamente reduzida de flagelados heterotróficos, quando comparada ao plâncton de lagos e reservatórios, pode estar relacionada ao fato de os fitotelmata serem habitats limitados, com condições ambientais extremas, selecionando, assim, organismos tolerantes a esses ambientes.

Palavras-chave: Aechmea distichantha, fitotelmata, protozoários, flagelados heterotróficos.

\section{Introduction}

Many plant species can accumulate rainwater through their outer surfaces, forming small aquatic habitats where associated organisms can live (Srivastava et al., 2004;
Williams, 2006). These characteristic microhabitats are called phytotelmata (from Greek, phyton = plant, telm = puddle), ranging from modified leaves, floral parts, leaf axils and 
fruit peel, to tree holes. They are common in pluvial forests, possibly due to the wide variety of microclimatic conditions, enormous variety of plant species and high humidity in tropical regions (Greeney, 2001; Kitching, 2004; Araújo et al., 2004).

Two species of bromeliads that form tanks capable of collecting and storing rainwater are found in the floodplain of the upper Paraná River, namely, Aechmea distichantha Lem. and Aechmea bromeliifolia (Rudge) Baker, of which the former is most abundant (Duarte et al., 2013; Buosi et al., 2014). A. distichantha is a terrestrial or facultative epiphyte, occurring in deciduous or semi-deciduous forests with wide distribution in South America, found in forests of southern Brazil, Bolivia, Paraguay, Uruguay and northern Argentina (Smith and Downs, 1979). Its leaves are pungent, may measure from 30 to 100 centimeters, and the specimens that are exposed to the sun can present leaves that are more extensive and tank-forming, supporting larger amounts of water (Cavallero et al., 2009).

The microhabitat created by the accumulation of water in foliar structures can be considered an "isolated limnological environment", harboring numerous species (Mestre et al., 2001), where this associated community offers nutrients to the plants, thus living in a relationship (Romero et al., 2006; Omena and Romero, 2008). Due to their size and defined boundaries, these plants can be considered as microcosms (Richardson, 1999), with examples known for studies of ecological interactions (Maguire Junior, 1971). These interactions exist through the variety of organisms that colonize plants, such as protists, invertebrates and vertebrates (Juncá and Borges, 2002; Buosi et al., 2014), which adapt to changes in the chemical composition of water and nutrient supply (Kitching, 2001).

Among the free-living protists of phytotelmata, the most important are flagellates, organisms of great importance in microbial food chains. Among them, heterotrophs are small in size, have a high metabolic rate (Fenchel, 1982), and are involved in the rapid remineralization of nutrients (Weisse, 1991). They are also major consumers of bacterial biomass (Schmidt-Halewicz, 1994; Simek et al., 1999), and can feed on viruses, dissolved organic carbon (Gasol et al., 1995) and cyanobacteria (Pernthaler et al., 1996). On the other hand, they may be prey to ciliates (Weisse, 1991; Berninger et al., 1993; Debastiani et al., 2016), copepods and cladocerans (Burns and Schallenberg, 2001).

According to Biyu (2000), the main factors in regulating protozoan populations are the quality and quantity of food, available habitats, temperature and predation, and feeding is probably the most relevant factor. Thus, flagellates actively participate in the microbial link directly affecting other organisms in aquatic food webs (Corliss, 2001).

In Brazil, studies involving protists, including the heterotrophic flagellate are still incipient (Pauleto et al. 2009; Camargo and Velho, 2010; Lansac-Toha et al., 2016), mainly due to methodological difficulties (Gomes and Godinho, 2003), the high cost of acquiring new equipment and the scarcity of taxonomists in this group (César and Abreu, 2001). In this context, the objective of this work was to conduct an inventory of the heterotrophic flagellates associated with the phytotelmata of bromeliads found in rocky walls of a stretch of the upper Paraná River.

\section{Material and Methods}

\subsection{Study site}

The study was carried out in the upper Paraná River basin, located between the mouth of the Paranapanema River and the mouth of the Ivinhema River, approximately $200 \mathrm{~km}$ upstream from Itaipu reservoir (Figure 1), in the last stretch of the river free of the dam in Brazilian territory (Takeda et al., 2002; Fernandes et al., 2009). The samples were collected on the left bank of the Paraná River, near the Advanced Research Base of Nupélia/UEM, located in the municipality of Porto Rico, State of Paraná. The region has an asymmetry between the two sides of the valley, with the left bank higher than the right bank, with walls formed by sedimentary rocks from the Cretaceous Period and sparse areas (Souza Filho and Stevaux, 2004). These walls allow epiphytes to establish themselves, among them bromeliads.

\subsection{Sampling}

The samples were collected from individuals of the species Aechmea distichantha, selected for their abundance on the rocky walls of the left bank of the Paraná River. The bromeliads were removed manually from the cliff-wall and then placed in plastic bags to keep the water present in the tanks. They were then transported to the Advanced Research Base of Nupélia in the municipality of Porto Rico, Paraná. In the laboratory, the water was removed from the tanks of each plant, which were also soon washed with distilled water, aiming at the removal of all organisms present in their tanks (Figures 2, 3).

\subsection{Laboratory analysis}

In the laboratory, cultures of the organisms were mounted on Petri dishes from aliquots of the live samples, where some crushed rice grains were added. Rice promotes the growth of bacteria and, therefore, the populations of heterotrophic flagellates, which were observed in vivo under a $1000 \mathrm{X}$ magnification Olympus BX51 optical microscope, equipped with differential interference contrast (DIC) system, for better visualization of flagellates. Films and photographs were taken for later identification of organisms.

The taxonomic framework followed for the classification of species identified in this study was according to the work of Adl et al. (2019), which adopts two Domains, Amorphea and Diaphoretiches. After identifying the species, the photos were used to make the schematic drawings, using the program Coreldraw X6.

The reference specimens were deposited at the Protoplankton Laboratory of the Núcleo de Pesquisas em Limnologia, Ictiologia e Aquicultura (Nupélia), State University of Maringá, Paraná, Brazil. 


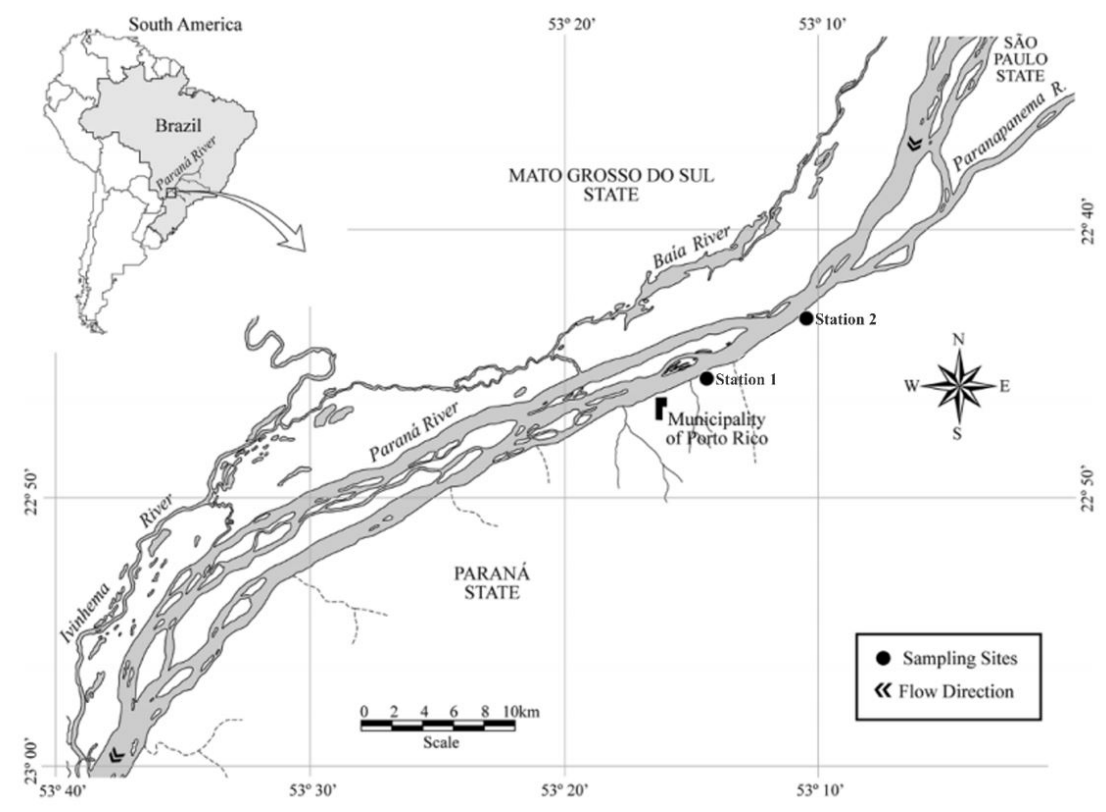

Figure 1. Sampling sites on the left bank of the Paraná River.

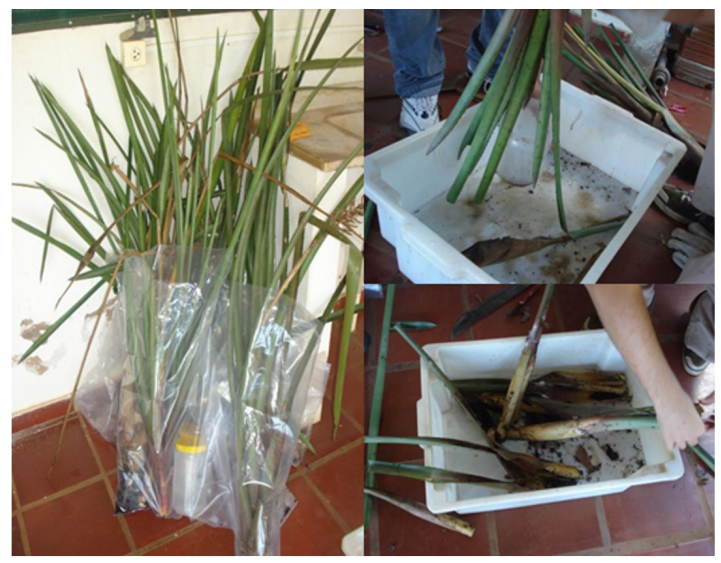

Figure 2. Procedures performed with the bromeliads, storage from collection to arrival at the Nupélia research base (left). Removal of water present in phytotelmata (photos on the right).

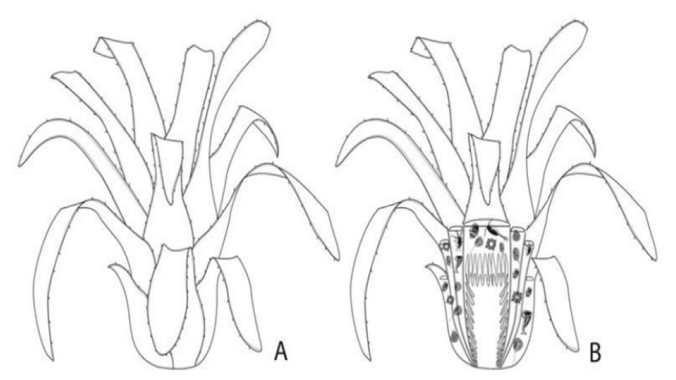

Figure 3. Schematic drawing of a bromeliad with the overlap of leaves in (A) and a longitudinal section of a bromeliad tank showing the community of organisms present in the plant in (B) Source: Duarte et al. (2013).

\section{Results}

Sixteen species of heterotrophic flagellate were recorded, one species belonging to the Amorphea Domain, and 15 species to the Diaphoretiches Domain. The most species-rich groups were Euglenida and Kinetoplastea, with four species registered in each one.

\section{Classification}

AMORPHA Adl et al., 2010

- Holozoa Lang et al., 2002

-• Choanoflagellida Kent, 1880-1882

•• Craspedida Cavalier-Smith, 1997

•.• Salpingoecidae Kent, 1880-1882

Monosiga ovata Kent, 1880-1882 (Figure 4)

Jeuck and Arndt, 2013, p. 10, pl. 8.

New records. Brazil: Paraná State: Porto Rico municipality: Paraná River, station $1\left(22^{\circ} 45^{\prime} 53^{\prime \prime} \mathrm{S}\right.$, $\left.53^{\circ} 15^{\prime} 27^{\prime \prime} \mathrm{W}\right)$; station 2 (22 $\left.43^{\prime} 11^{\prime \prime} \mathrm{S}, 53^{\circ} 10^{\prime} 46^{\prime \prime} \mathrm{W}\right)$, Fernando Miranda Lansac-Tôha, 04.VII.2013.

Identification. Ovate cell, with $6 \mu \mathrm{m}$ in width and $10 \mu \mathrm{m}$ in length; $25 \mu \mathrm{m}$ measured from the tip of the flagella at the distal end of the stem. Anterior end of the cell with 20 to 25 tentacles, almost equal in length, forming a ring that surrounds the single flagellum. The body of the cell and the base of the tentacles are closely lined by a delicate membranous sheath, which is subsequently tapered to form the stem or peduncle that connects the cell to the substrate.

Comments. This species was previously recorded in samples of plankton in the State of Rio de Janeiro (Cunha, 1913) and in the State of Mato Grosso do Sul in lagoons of the high Paraná River floodplain (Camargo and Velho, 2010; Lansac-Tôha et al., 2016). 


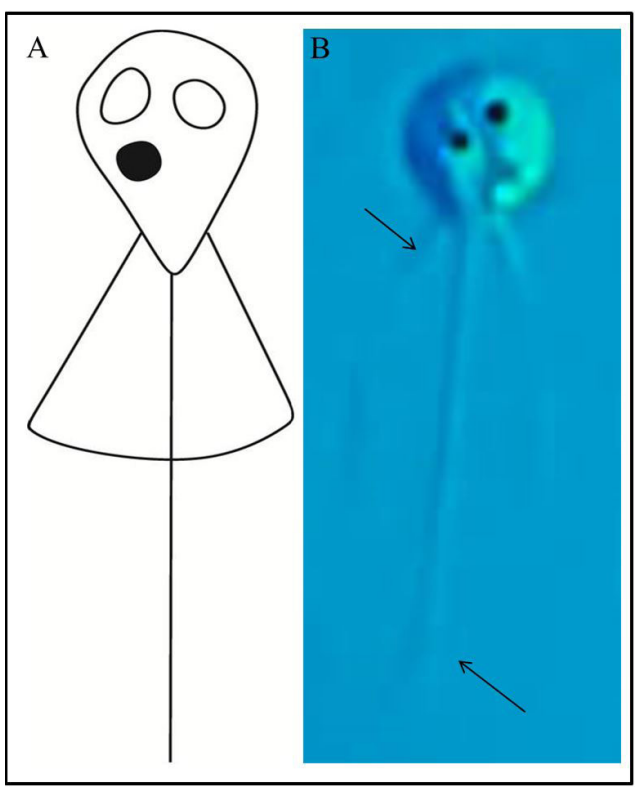

Figure 4. Monosiga ovata. (A) Schematic drawing; (B) Photo, where the upper arrow indicates the ring surrounding the flagellum and the lower arrow indicates the termination of the flagellum. Scale of $5 \mu \mathrm{m}$.

DIAPHORETICHES Adl et al., 2012

-Stramenopiles Patterson, 1989

••Bigyra Cavalier-Smith, 1998

*.Opalozoa Cavalier-Smith, 1998

•..•Bicosoecida Grasse, 1926

Bicosoeca vacillans Stolcm, 1888 (Figure 5)

Tong et al., 1997, p. 98-99, fig. 4 E, I, K, M, fig. 5 E.

New records. Brazil: Paraná State: Porto Rico municipality: Paraná River, station 1 ( $22^{\circ} 45^{\prime} 53^{\prime}$ ' S, $\left.53^{\circ} 15^{\prime} 27^{\prime \prime} \mathrm{W}\right)$; station $2\left(22^{\circ} 43^{\prime} 11^{\prime \prime} \mathrm{S}, 53^{\circ} 10^{\prime} 46^{\prime \prime} \mathrm{W}\right)$, Fernando Miranda Lansac-Tôha, 04.VII.2013.

Identification. Rounded, biflagellate cell, about $6 \mu \mathrm{m}$, slightly flattened top from which the anterior flagellum emerges, approximately three times the size of the cell. Cell located in a loric with a chamber $18 \mu \mathrm{m}$, approximately cylindrical, with the posterior part slightly pointed. A $20 \mu \mathrm{m}$ posterior flagellum through which the cell attaches to the substrate, attached to the base of the loric by a small filament.

Comments. The loric size found in this study is within the range of 17 to $25 \mu \mathrm{m}$ (see Tong et al., 1997). This species was previously recorded in freshwater environments of the Northern Hemisphere (Picken, 1941; Tong et al., 1997).

•-Gyrista Cavalier-Smith, 1998

•.Ochrophyta Cavalier-Smith, 1986

•..•Chrysista Cavalier-Smith, 1986

....•Chrysophyceae Pascher, 1914

•...•Paraphysomonadida Scoble and Cavalier-

Smith, 2014

Paraphysomonas vestita (Stokes, 1885) Saedeleer, 1929 (Figure 6)

Tong et al., 1997, p. 101, fig. 4 N, fig. 5 A.

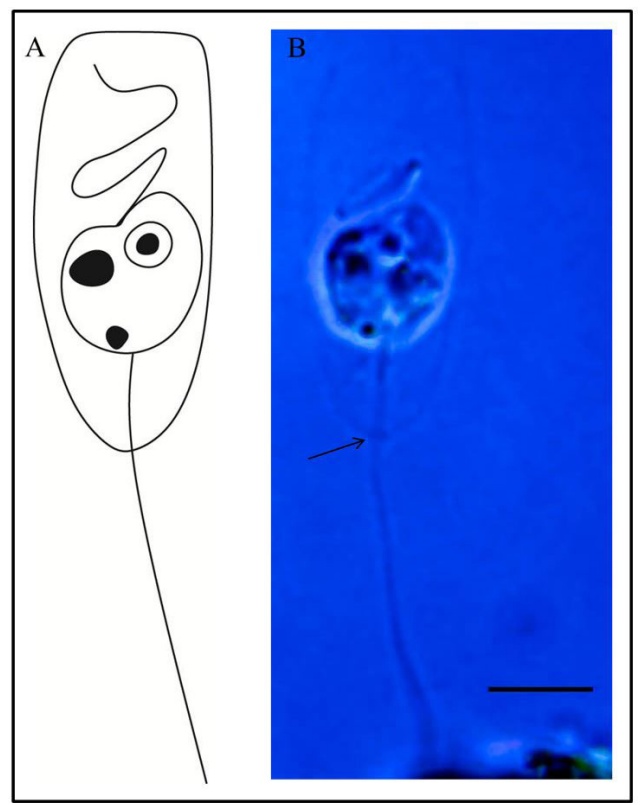

Figure 5. Bicosoeca vacillans. (A) Schematic drawing; (B) Photo, where the arrow indicates the filament of the base of the loric. Scale of $5 \mu \mathrm{m}$.

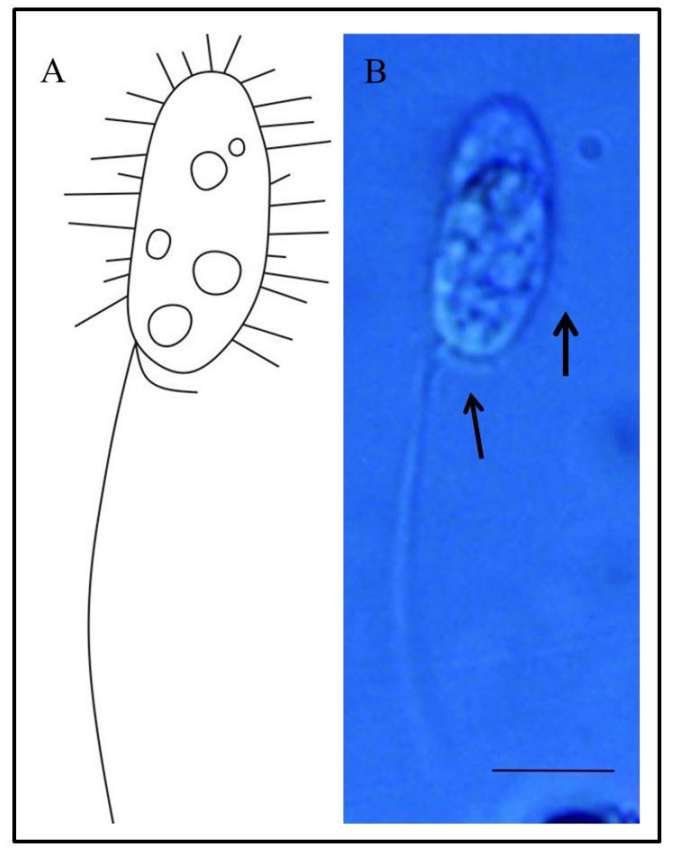

Figure 6. Paraphysomonas vestita. (A) Schematic drawing; (B) Photo, where the arrow indicates the short flagella. C. Photo, where the arrow indicates the spicules. Scale of $5 \mu \mathrm{m}$.

New records. Brazil: Paraná State: Porto Rico municipality: Paraná River, station $1\left(22^{\circ} 45^{\prime} 53^{\prime \prime} \mathrm{S}\right.$,

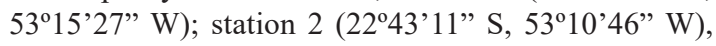
Fernando Miranda Lansac-Tôha, 04.VII.2013. 
Identification. Cell with about $10 \mu \mathrm{m}$ in length and $5 \mu \mathrm{m}$ in width. Presence of a short flagellum $5 \mu \mathrm{m}$ long and another flagellum around the length of the cell, attached to the substrate, and extending from the back of the cell. Pellicle coated with a layer of delicate spicules. Presence of several contractile vacuoles, digestive vacuoles and vacuoles with storage product.

Comments. Species with wide distribution in marine and freshwater environments (Preisig and Hibberd, 1982; Tong et al., 1997).

-Cryptista Adl et al., 2019

-Cryptophyceae Pascher, 1913

Chilomonas paramecium Ehrenberg, 1831 (Figure 7)

Castro et al., 1991, p. 20, figs. 72-74; Lee et al., 2005, p. 328, fig. 3 B; Castro and Bicudo, 2007, p. 123, figs. 17-22.

New records. Brazil: Paraná State: Porto Rico municipality: Paraná River, station 1 ( $22^{\circ} 45^{\prime} 53^{\prime \prime} \mathrm{S}$,

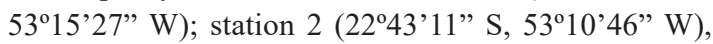
Fernando Miranda Lansac-Tôha, 04.VII.2013.

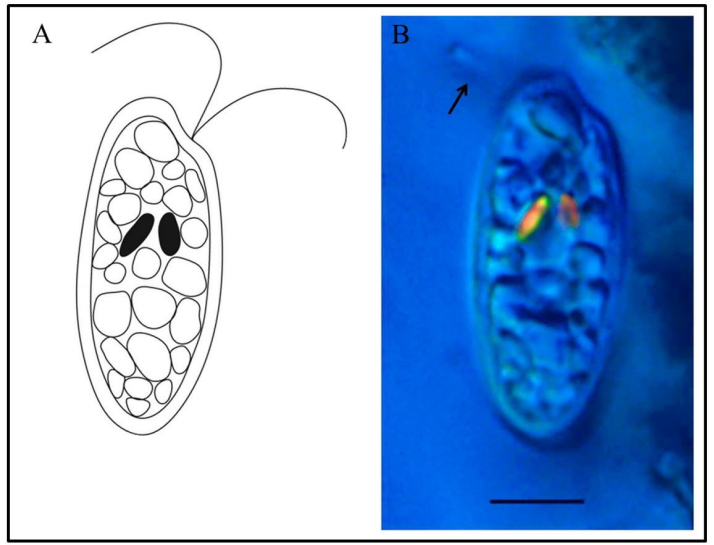

Figure 7. Chilomonas paramecium. (A) Schematic drawing; (B) Photo, where the arrow indicates one of the flagella. Scale of $5 \mu \mathrm{m}$.
Identification. Rigid and elongated cell, with $20 \mu \mathrm{m}$ in length and $8 \mu \mathrm{m}$ in width. In lateral view, the dorsal anterior part of the cell is more prominent. Presence of two flagella that emerge from the apical part of the cell, with about $10 \mu \mathrm{m}$ each. Two Maupa corpuscles of different sizes, located ventrally. Swiveling movement while swimming.

Comments. A species widely distributed in marine and freshwater environments (Lee et al., 2005) and commonly found in environments rich in organic matter (Arndt et al., 2000). Recorded in Brazil, in continental aquatic environments, in the States of Santa Catarina, São Paulo, Rio de Janeiro, Minas Gerais, Ceará, Piauí and Mato Grosso do Sul (see Cunha, 1913; Castro et al., 1991; Castro and Bicudo, 2007; Lansac-Tôha et al., 2016).

Goniomonas truncata (Fresenius, 1858) Stein, 1878 (Figure 8)

Ekelund and Patterson, 1997, p. 463, fig. 1F; Lee et al., 2005, p. 325, figs. $1 \mathrm{~J}$ and $3 \mathrm{~J}$; Castro and Bicudo, 2007, p. 125 , fig. $140-143$.

New records. Brazil: Paraná State: Porto Rico municipality: Paraná River, station $1\left(22^{\circ} 45^{\prime} 53^{\prime \prime} \mathrm{S}\right.$, $\left.53^{\circ} 15^{\prime} 27^{\prime \prime} \mathrm{W}\right)$; station 2 (22 $\left.43^{\prime} 11^{\prime \prime} \mathrm{S}, 53^{\circ} 10^{\prime} 46^{\prime \prime} \mathrm{W}\right)$, Fernando Miranda Lansac-Tôha, 04.VII.2013.

Identification. Oval cell, with flat anterior margin, $15 \mu \mathrm{m}$ in length and $10 \mu \mathrm{m}$ in width. Striated pellicle, with globular or navicular ejectisomes, circling apically the anterior pole. Presence of two subapical flagella similar in size to cell length.

Comments. Common species in continental aquatic environments. It can be distinguished from G. amphinema and G. pacifica because of its larger size (Lee et al., 2005). In Brazil, there are records for the states of Santa Catarina, São Paulo, Rio de Janeiro, Minas Gerais, Ceará and Mato Grosso do Sul, in freshwater samples (see Cunha, 1913; Castro et al., 1991; Castro and Bicudo, 2007; Lansac-Tôha et al., 2016).

-Metamonoda Grasse, 1952

••Fornicata Simpson, 2003

•••Diplomonadida Wienyon, 1926

•••Hexamitinae Kent, 1880-1882

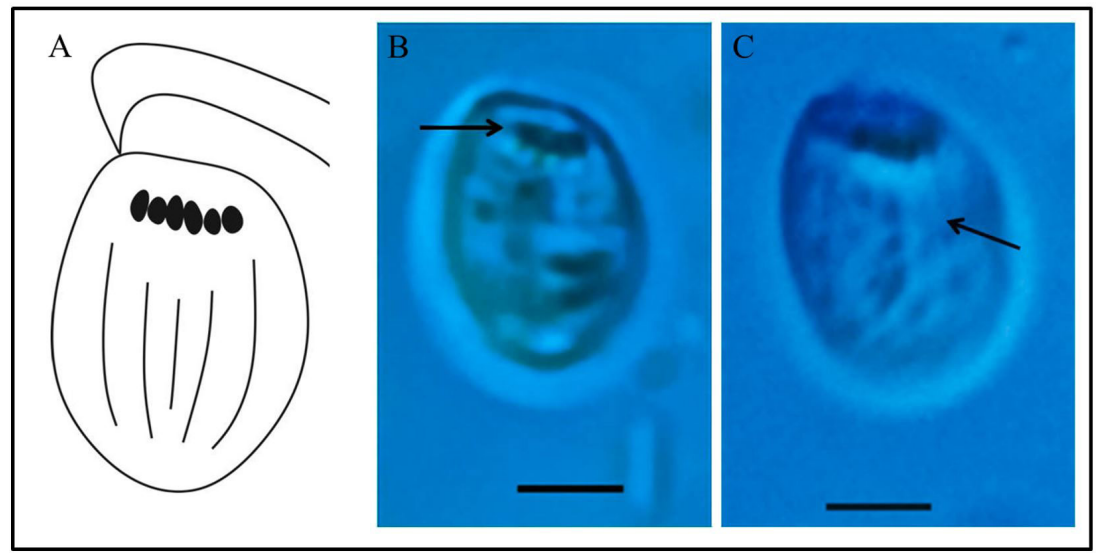

Figure 8. Goniomonas truncata. (A) Schematic drawing; (B) Photo, where the arrow indicates the globular ejectisomes; (C) Photo, where the arrow indicates the striated pellicle. Scale of $5 \mu \mathrm{m}$. 
Hexamita inflata Dujardin, 1838 (Figure 9)

Jeuck and Arndt, 2013, p. 849, pl. 6.

New records. Brazil: Paraná State: Porto Rico municipality: Paraná River, station 1 (22 $45^{\prime} 53^{\prime}$ 'S,

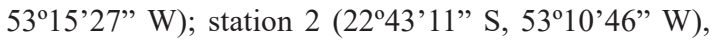
Fernando Miranda Lansac-Tôha, 04.VII.2013.

Identification. Ovoid cell, about $15 \mu \mathrm{m}$ in length and $12 \mu \mathrm{m}$ in width. Presence of two lateral channels at the anterior end, from which emerge two flagella, about $10 \mu \mathrm{m}$ each. The posterior end of the pointed or rounded cell from which other flagella emerge.

Comments. This species occurs exclusively in freshwater environments, having been recorded even in streams (Tikhonenkov and Mazei, 2007).

-Discoba Simpson in Hampl et al., 2009

••Euglenozoa Cavalier-Smith, 1981

$\bullet$ Euglenida Butschli, 1884

•••Heteronematina Leedale, 1967

Entosiphon sulcatum (Dujardin, 1841) Stein, 1878 (Figure 10)

Larsen and Patterson, 1990, p. 867, fig. 28 A; Schroeckh et al., 2003, p. 140-141, fig. 2 O-P; Lee et al., 2005, p 325, fig., 1 G, p. 328, fig. 3 G-I.

Records. Brazil: Paraná State: Porto Rico municipality: Paraná River, station 1 (22 $45^{\circ} 53^{\prime}$ S, 53 ${ }^{\circ} 15^{\prime} 27^{\prime}$ W); station 2 (22 $43^{\prime} 11^{\prime \prime} \mathrm{S}, 53^{\circ} 10^{\prime} 46^{\prime}$ "W), Fernando Miranda Lansac-Tôha, 04.VII.2013.

Identification. Oblong to ovate cell, $15 \mu \mathrm{m}$ in length and $7 \mu \mathrm{m}$ in width. Presence of two emerging flagella, the former actively beating, approximately the length of the cell; and the latter, the drag, about 1.5 times the size of the cell. Developed siphon that can project from the cell. Contractile vacuole and evident nucleus.

Comments. Cell length is one of the smallest already reported in the literature, but within the range presented by Schroeckh et al. (2003) of 15 to $40 \mu \mathrm{m}$. This species is often recorded in freshwater environments (Schroeckh et al., 2003; Lee et al., 2005), but also in marine environments (Larsen and Patterson, 1990). It was recorded in plankton samples in the State of Rio de Janeiro and Mato Grosso do Sul (Cunha, 1913; Lansac-Tôha et al., 2016) and in samples of bromeliads of rocky shores of the Paraná River, State of Paraná (Duarte et al., 2013).

Petalomonas abscissa (Dujardin, 1841) Stein, 1878 (Figure 11)

Ekebom et al., 1996, p. 260, figs. $4 \mathrm{G}$ and 5 D; Al-Qassab et al., 2002, p. 109-110, fig. 1 N; Schroeckh et al., 2003, p. 153, figs. $3 \mathrm{~N}-\mathrm{O}$ and 6 L-M.

New records. Brazil: Paraná State: Porto Rico municipality: Paraná River, station $1\left(22^{\circ} 45^{\prime} 53^{\prime \prime} \mathrm{S}\right.$, $\left.53^{\circ} 15^{\prime} 27^{\prime \prime} \mathrm{W}\right)$; station 2 (22 $\left.43^{\prime} 11^{\prime \prime} \mathrm{S}, 53^{\circ} 10^{\prime} 46^{\prime \prime} \mathrm{W}\right)$, Fernando Miranda Lansac-Tôha, 04.VII.2013.

Identification. Rigid cell, with oval to triangular shape, $13 \mu \mathrm{m}$ in length and $10 \mu \mathrm{m}$ in width. Dorsal part with two distinct grooves. Emerging flagella, with the same cell length. Cell with swimming displacement toward the flagella.

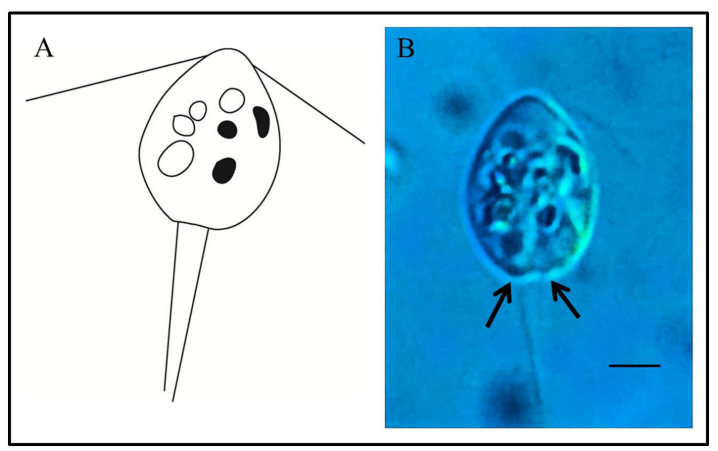

Figure 9. Hexamita inflata. (A) Schematic drawing; (B) Photo, where the arrows indicate the side channels. Scale of $5 \mu \mathrm{m}$.

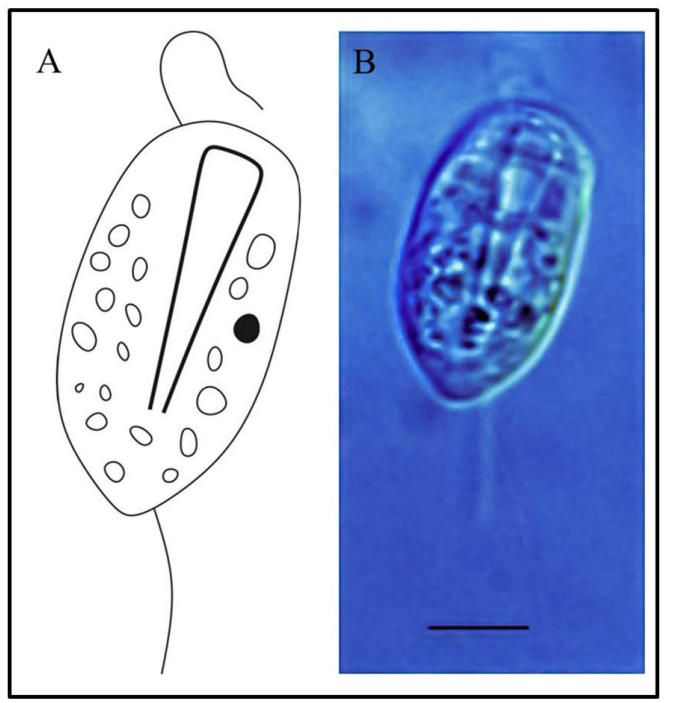

Figure 10. Entosiphon sulcatun. (A) Schematic drawing; (B) Photo, where the arrow indicates the opening of the siphon. Scale of $5 \mu \mathrm{m}$.

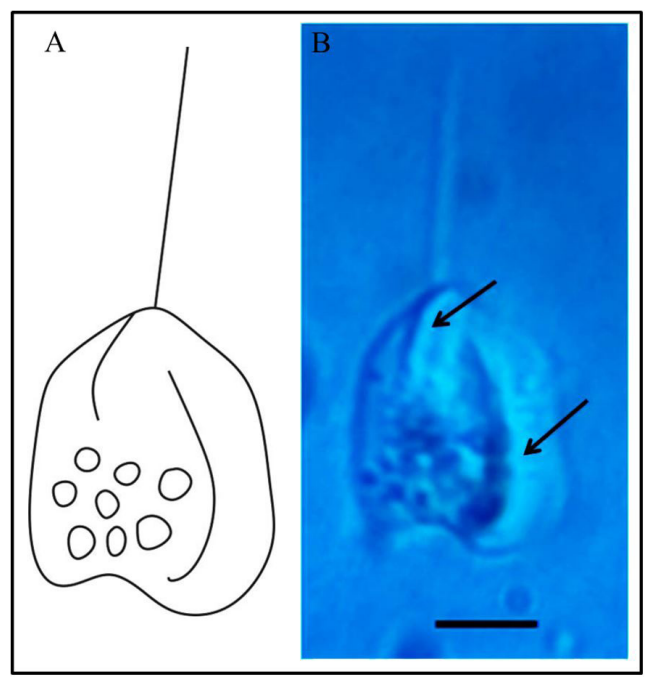

Figure 11. Petalomonas abscissa. (A) Schematic drawing; (B) Photo, where the arrows indicate the dorsal grooves. Scale of $5 \mu \mathrm{m}$. 


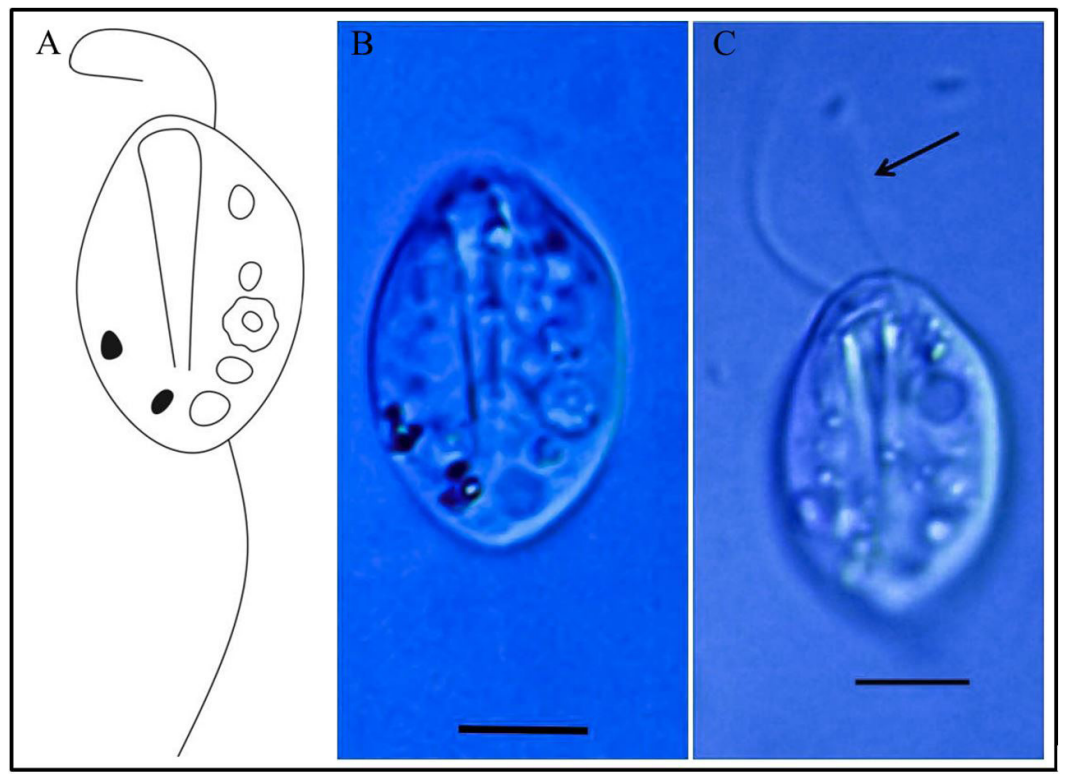

Figure 12. Ploeotia obliqua. (A) Schematic drawing; (B) and (C) Photos, where the arrow indicates the flagella. Scale of $5 \mu \mathrm{m}$.

Comments. The shape of the cell can be very varied (triangular, oval or rounded) and the size of the cell may have a large variation $(10-30 \mu \mathrm{m})$. Species registered in marine and freshwater environments of the Northern and Southern Hemispheres (see Schroeckh et al., 2003). In Brazil, it was recorded in Rio de Janeiro in marine benthic samples (Larsen and Patterson, 1990).

Ploeotia obliqua (Klebs, 1893) Schroeckh et al., 2003 (Figure 12)

Schroeckh et al., 2003, p. 158, figs. 4 K-N, and 7 N; Lee et al., 2005, p. 337, figs. 7 A and 8 F-G.

New records. Brazil: Paraná State: Porto Rico municipality: Paraná River, station $1\left(22^{\circ} 45^{\prime} 53^{\prime \prime} \mathrm{S}\right.$, $\left.53^{\circ} 15^{\prime} 27^{\prime \prime} \mathrm{W}\right)$; station $2\left(22^{\circ} 43^{\prime} 11^{\prime \prime} \mathrm{S}, 53^{\circ} 10^{\prime} 46^{\prime \prime} \mathrm{W}\right)$, Fernando Miranda Lansac-Tôha, 04.VII.2013.

Identification. Rigid sliding cell, obovate, slightly flattened dorsoventrally, about $14 \mu \mathrm{m}$ in length and $10 \mu \mathrm{m}$ in width. Presence of two flagella unequal in length, the anterior flagellum approximately the same cell size and with active beating during swimming; the drag flagellum, with approximately 2.5 times the cell size. Presence of siphon, pellicle with four longitudinal ribs.

Comments. The species of the genus Ploeotia resemble the genus Entosiphon in relation to the cellular contour, number and length of the flagella, appearance of the siphon and movement. However, Ploeotia is distinguished from Entosiphon by presenting a non-projectable siphon. Ploeotia obliqua found in this study has measurements of length and width similar to the original description. This species was originally described as Entosiphon obliquum Klebs, 1893. It was transferred to the genus Ploeotia by presenting the siphon with pumping motion, which is not observed in Entosiphon. It has a wide geographical distribution (Schroeckh et al., 2003). This species was

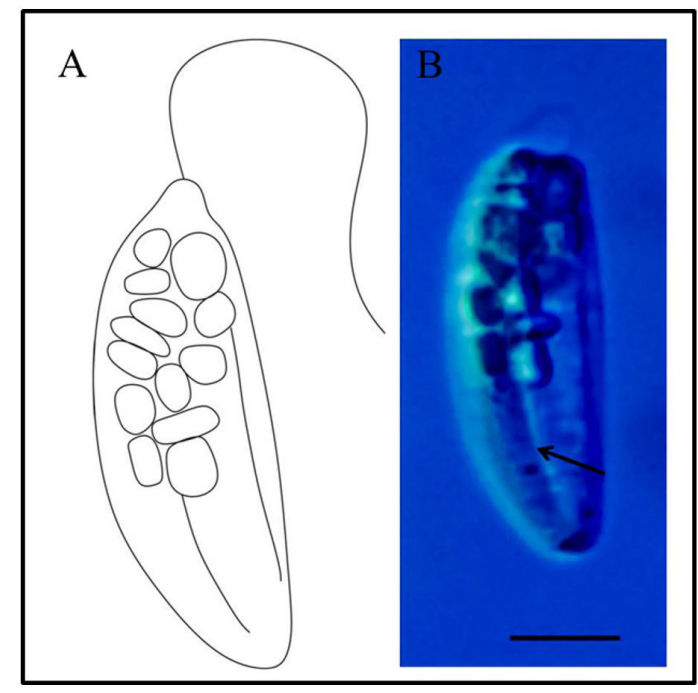

Figure 13. Rhabdomonas incurva. (A) Schematic drawing; (B) Photo, where the arrow indicates the longitudinal groove. Scale of $5 \mu \mathrm{m}$.

previously recorded in samples of plankton in lagoons of the high Paraná River floodplain, State of Mato Grosso do Sul (Lansac-Tôha et al., 2016).

....Aphagea Cavalier-Smith, 1993

Rhabdomonas incurva (Fresenius, 1858) Klebs, 1893 (Figure 13)

Schroeckh et al., 2003, p. 159, figs 8 O-R and 9 A-C.

New records. Brazil: Paraná State: Porto Rico municipality: Paraná River, station $1\left(22^{\circ} 45^{\prime} 53^{\prime \prime} \mathrm{S}\right.$, $\left.53^{\circ} 15^{\prime} 27^{\prime \prime} \mathrm{W}\right)$; station $2\left(22^{\circ} 43^{\prime} 11^{\prime \prime} \mathrm{S}, 53^{\circ} 10^{\prime} 46^{\prime \prime} \mathrm{W}\right)$, Fernando Miranda Lansac-Tôha, 04.VII.2013. 
Identification. Rigid, cylindrical, banana-shaped cell, about $20 \mu \mathrm{m}$ in length and $6 \mu \mathrm{m}$ in width. Presence of longitudinal grooves in the cell. The only flagellum, inserted in the apical region of the cell, has approximately the same cell length. Swirling around the longitudinal axis.

Comments. This species presents a wide geographical distribution in freshwater environments (Schroeckh et al., 2003)

$\bullet$ Kinetoplastea Honigberg, 1963

•.•-Metakinetoplastina Vickeman in Moreira et al., 2004

•...Neobodonida Vickeman in Moreira et al., 2004

Neobodo designis (Skuja, 1948) Moreira et al., 2004 (Figure 14)

Larsen and Patterson, 1990, p. 817, fig. 5 A-F; Al-Qassab et al., 2002, p. 97, fig. 1 J.; Lee et al. 2005, p. 331, fig. 4 B.

New records. Brazil: Paraná State: Porto Rico municipality: Paraná River, station 1 (22 $45^{\prime} 53^{\prime \prime} \mathrm{S}$,

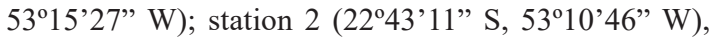
Fernando Miranda Lansac-Tôha, 04.VII.2013.

Identification. Elliptical cell, $7 \mu \mathrm{m}$ in length and $5 \mu \mathrm{m}$ in width. Two unequal flagella inserted into a small flagellar pocket originating from a rostral region in the apical part of the cell. The anterior flagellum is almost the same length as the cell, and the posterior flagellum is about $25 \mu \mathrm{m}$. Swift rotating motion while swimming, with the anterior flagellum wrapped around the cell.

Comments. This species was recently classified in the genus Neobodo, through molecular sequencing studies (18S rRNA), by Moreira et al. (2004). It presents records in marine and freshwater environments in various parts of the world (see Lee et al., 2005). In Brazil, it was recorded in marine benthic samples in the State of Rio de Janeiro, as Bodo designis (Larsen and Patterson, 1990) and in in samples of plankton in lagoons of the high Paraná River floodplain, State of Mato Grosso do Sul (Lansac-Tôha et al., 2016).

Rhynchobodo simius Patterson and Simpson, 1996 (Figure 15)

Patterson and Simpson, 1996, p. 424, figs. 1 J-O and 2 G-H; Al-Qassab et al., 2002, p. 98, figs. $1 \mathrm{~N}$ and $2 \mathrm{~J}$.

New records. Brazil: Paraná State: Porto Rico municipality: Paraná River, station $1\left(22^{\circ} 45^{\prime} 53^{\prime \prime} \mathrm{S}\right.$, $\left.53^{\circ} 15^{\prime} 27^{\prime \prime} \mathrm{W}\right)$; station 2 (22 $\left.43^{\prime} 11^{\prime \prime} \mathrm{S}, 53^{\circ} 10^{\prime} 46^{\prime \prime} \mathrm{W}\right)$, Fernando Miranda Lansac-Tôha, 04.VII.2013.

Identification. Fusiform cell, about $10 \mu \mathrm{m}$ in length and $5 \mu \mathrm{m}$ in width. Apical part of the cell with an opening (rostrum) at the end from which emerge two flagella, the former slightly larger than the size of the cell and the posterior about three times larger. A large posterior feeding vacuole may occur.

Comments. Most common species in marine environments, in which it was originally described (Patterson and Simpson, 1996), being less frequent in freshwater environments.

Dimastigella trypaniformis Sandon, 1928 (Figure 16)

Tong et al., 1997, p. 528, figs. $6 \mathrm{~J}$ and 7 F-J.; Tong et al., 1998, p. 176, figs. $5 \mathrm{~F}$ and $6 \mathrm{H}$; Jeuck and Arndt, 2013, p. 853, pl. 10.

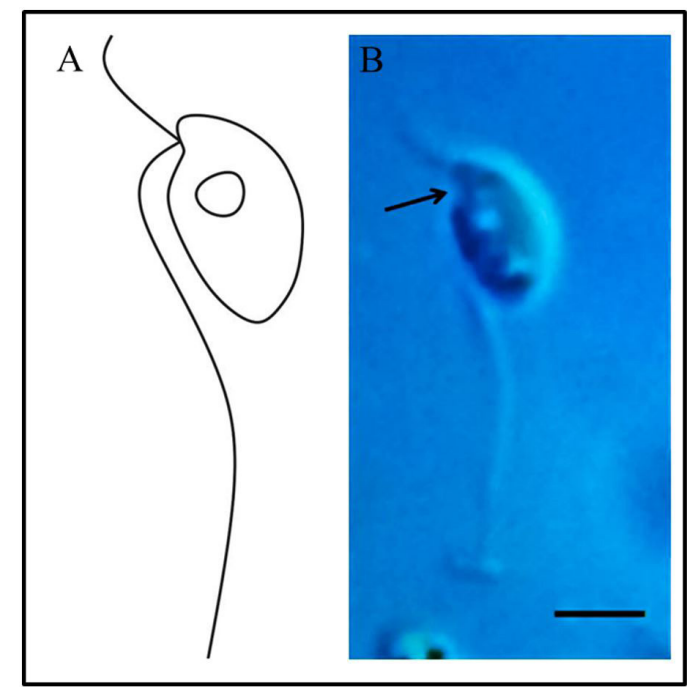

Figure 14. Neobodo designis. (A) Schematic drawing; (B) Photo, where the arrow indicates the apical flagellar pocket. Scale of $5 \mu \mathrm{m}$.

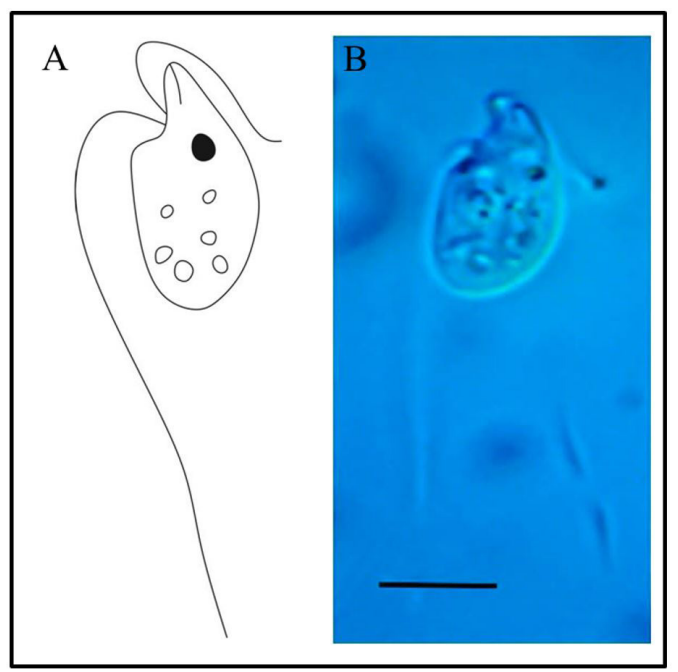

Figure 15. Rhynchobodo simius. (A) Schematic drawing; (B) Photos. Scale of $5 \mu \mathrm{m}$.

New records. Brazil: Paraná State: Porto Rico municipality: Paraná River, station $1\left(22^{\circ} 45^{\prime} 53^{\prime \prime} \mathrm{S}\right.$, $\left.53^{\circ} 15^{\prime} 27^{\prime \prime} \mathrm{W}\right)$; station 2 (22 $\left.43^{\prime} 11^{\prime \prime} \mathrm{S}, 53^{\circ} 10^{\prime} 46^{\prime \prime} \mathrm{W}\right)$, Fernando Miranda Lansac-Tôha, 04.VII.2013.

Identification. Elongated fusiform cell, with granules, about $5 \mu \mathrm{m}$ in length and $3 \mu \mathrm{m}$ in width. Presence of two flagella inserted apically, the former almost the size of the cell, swims actively, the posterior drag, adjacent along the entire length of the body with about twice the cell size.

Comments. The species presented smaller cellular dimensions than those recorded by Tong et al. (1998). It presents records in aquatic environments, soils and even in termite stomachs (Tong et al., 1998; Jeuck and Arndt, 2013). 


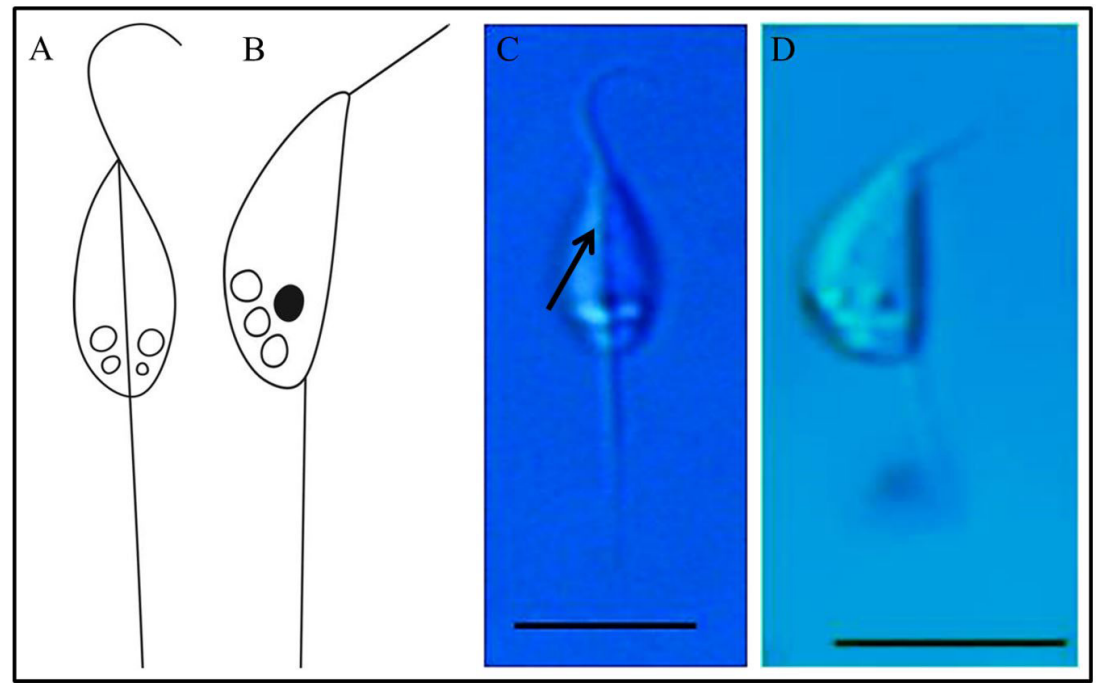

Figure 16. Dimastigella trypaniformis. (A) and (B) Schematic drawing; (C) and (D) Photos, where the arrow indicates the flagella adjacent to the cell. Scale of $5 \mu \mathrm{m}$.

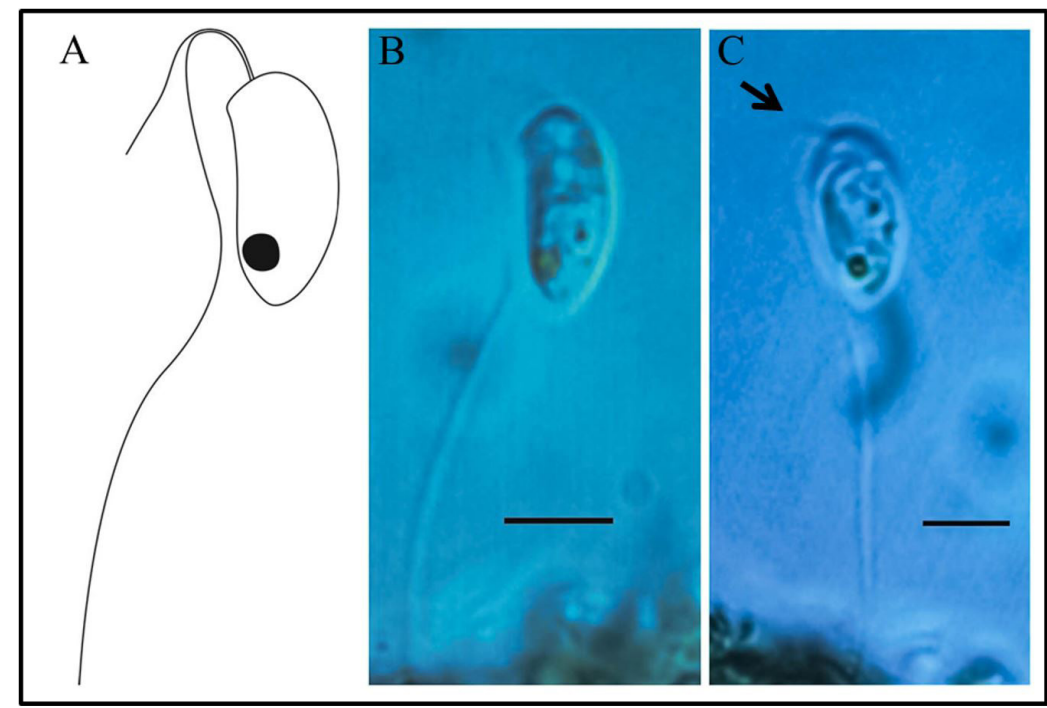

Figure 17. Bodo saltans. (A) Schematic drawing; (B) and (C) Photos, where the arrow indicates the previous flagella. Scale of $5 \mu \mathrm{m}$.

•.••Eubodonida Vickeman in Moreira et al., 2004

Bodo saltans Ehrenberg, 1832 (Figure 17)

Patterson and Simpson, 1996 p. 424, figs. 1 D-G and 2 E; Tong et al., 1997, p. 94, fig. 3 C; Al-Qassab et al., 2002, p. 97 , figs., $1 \mathrm{~K}$ and $2 \mathrm{I}$; Lee et al., 2005, p. 325, figs. $1 \mathrm{D}$ and $3 \mathrm{~A}$.

Records. Brazil: Paraná State: Porto Rico municipality: Paraná River, station 1 (22 $45^{\circ} 53^{\prime}$ S, 53 $15^{\circ} 27^{\prime}$ W); station 2 (22 $\left.43^{\prime} 11^{\prime \prime} \mathrm{S}, 53^{\circ} 10^{\prime} 46^{\prime \prime} \mathrm{W}\right)$, Fernando Miranda Lansac-Tôha, 04.VII.2013.

Identification. Elongated and elliptical cell, about $6 \mu \mathrm{m}$ in length and $4 \mu \mathrm{m}$ in width. Two flagella emerge from a sub apical depression, the former curved and sometimes adjacent to the body, with about $5 \mu \mathrm{m}$; the posterior also curved, often attached to the substrate, about $25 \mu \mathrm{m}$. During locomotion, the cell moves by jumps through the posterior flagella, this movement being characteristic of the species.

Comments. This species is easily identified in live samples by its characteristic movement. Common in freshwater environments, but has also been recorded in salty to hyper-saline environments (see Lee et al., 2005). In Brazil, it was recorded in plankton samples in the State of Rio de Janeiro (Cunha, 1913); in marine benthic samples from the State of Rio de Janeiro (Larsen and Patterson, 1990); in samples of bromeliads of rocky shores of the Paraná River, State of Paraná (Duarte et al., 2013); and in samples of plankton in lagoons of the upper Paraná River floodplain, State of Mato Grosso do Sul (Lansac-Toha et al., 2016). 


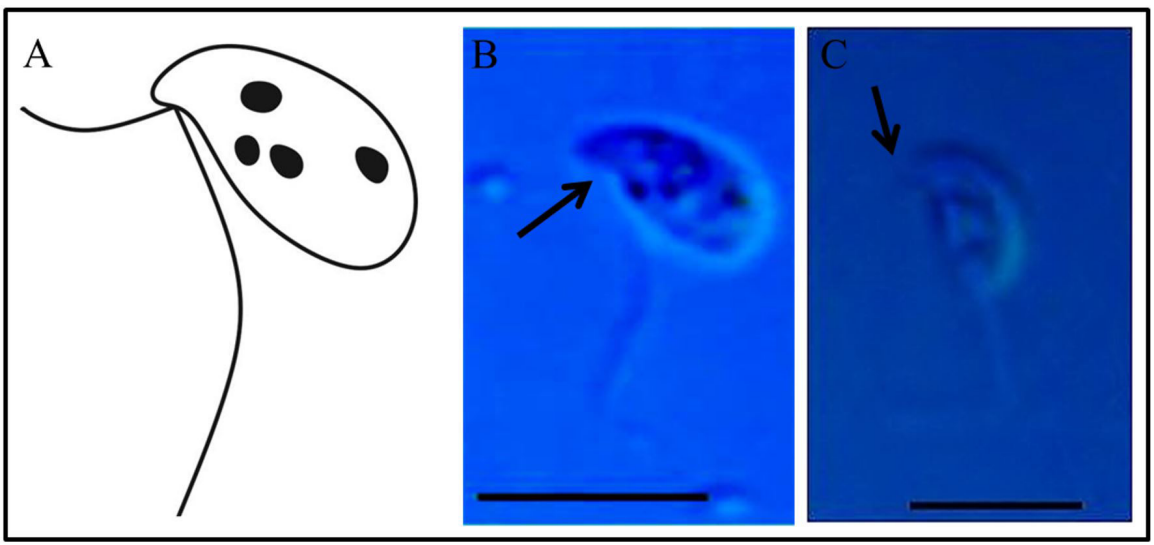

Figure 18. Ancyromonas sigmoides. (A) Schematic drawing; (B) Photo, where the arrow indicates the depression of the cell from where the flagella emerge; (C) Photo, where the arrow indicates the lower anterior flagella. Scale of $5 \mu \mathrm{m}$.

-Ancyromonadida Cavalier-Smith, 1998 [= Phanomonadida Cavalier-Smith, 2008]

Ancyromonas sigmoides Kent, 1880 (Figure 18)

Al-Qassab et al., 2002, p. 138, figs. $17 \mathrm{~S}$ and 18; Heiss et al., 2011, p. 375, fig. 1.

New records. Brazil: Paraná State: Porto Rico municipality: Paraná River, station 1 (22 $45^{\prime} 53^{\prime \prime} \mathrm{S}$, $\left.53^{\circ} 15^{\prime} 27^{\prime \prime} \mathrm{W}\right)$; station 2 (22 $\left.43^{\prime} 11^{\prime \prime} \mathrm{S}, 53^{\circ} 10^{\prime} 46^{\prime \prime} \mathrm{W}\right)$, Fernando Miranda Lansac-Tôha, 04.VII.2013.

Identification. Oval kidney-shaped cell, dorsoventrally depressed, about $4 \mu \mathrm{m}$ in length and $3 \mu \mathrm{m}$ in width. Presence of two flagella inserted in a dorsal depression, one smaller with about half of the cell and the other with approximately double the cell length.

Comments. This species was originally described in marine environments; however, it has also been recorded in continental aquatic environments (Heiss et al., 2011). This species was previously recorded in samples of plankton in lagoons of the high Paraná River, State of Mato Grosso do Sul (Lansac-Tôha et al., 2016).

Nutomonas limna Glucksman et al., 2013 (Figure 19)

Glucksman et al., 2013, p. 191, fig. 7 A, B, Y, Z.

New records. Brazil: Paraná State: Porto Rico municipality: Paraná River, station 1 (22 $45^{\prime} 53^{\prime \prime} \mathrm{S}$,

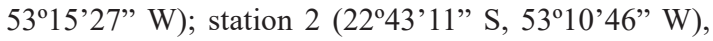
Fernando Miranda Lansac-Tôha, 04.VII.2013.

Identification. Bean-shaped cell, approximately $4 \mu \mathrm{m}$, with a rostrum, in which is inserted a single flagellum, slightly larger than the cell size. Swimming through the flagella, pushing the cell to perform movements of approximately $45^{\circ}$ from one side to another.

Comments. Glüksman et al. (2013) reviewed the genera Planomonas and Ancyromonas describing some species of the same that were included in two new genera, Fabomonas, marine, and Nutomonas, of fresh water, among them Nutomonas limna. The distinction between the species of Nutomonas was made by the small size of this species and the great prominence of its face.

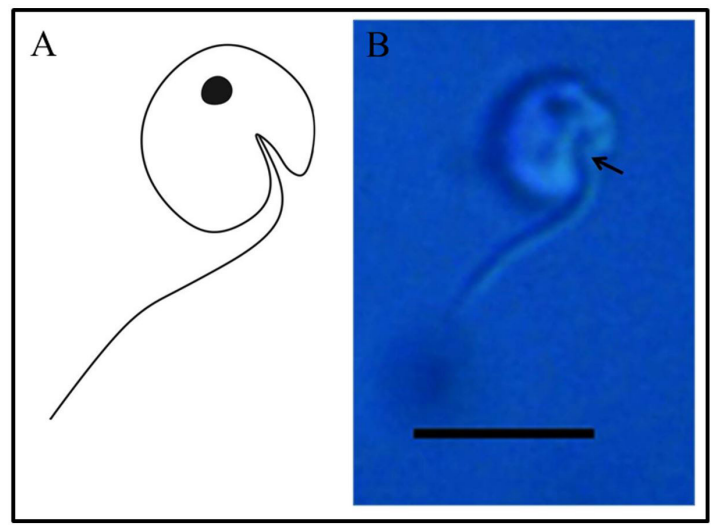

Figure 19. Nutomonas limna. (A) Schematic drawing; (B) Photo, where the arrow indicates the rostrum. Scale of $5 \mu \mathrm{m}$.

\section{Discussion}

The number of heterotrophic flagellate species identified in this study ( 16 species) is rather lower than other taxonomic studies performed with these protists, such as that of Schroeckh et al. (2003), who described 36 species and Ekebom et al. (1996), who described 37 species. Perhaps the smaller diversity found in bromeliads is due to the limited microcosm that is the phytotelma, in addition to the fact that it is still little explored by researchers, requiring more in-depth studies to better understand the environment.

The bromeliad microcosm is an environment with extreme conditions, with an excess of organic matter, thus selecting organisms that are tolerant to these environments. Therefore, colorless euglenids are normally abundant in eutrophic aquatic environments, feeding on both bacteria and organic solutes (Sanders, 1991).

This is one of the first works to focus on the taxonomy of flagellates in Brazil, since these protists are still very little known in continental Brazilian aquatic environments, and in particular, the heterotrophic flagellates associated with phytotelmata. 


\section{Acknowledgements}

We thank to CNPq and Capes for scholarsips and NupéliaPGB-PEA/UEM by the logistic support. We also thank to anonymous reviewers for suggestions to the manuscript.

\section{References}

ADL, S.M., BASS, D., LANE, C.E., LUKEŠ, J., SCHOCH, C.L., SMIRNOV, A., AGATHA, S., BERNEY, C., BROWN, M.W., BURKI, F., CÁRDENAS, P., ČEPIČKA, I., CHISTYAKOVA, L., DEL CAMPO, J., DUNTHORN, M., EDVARDSEN, B., EGLIT, Y., GUILlOU, L., HAMPL, V., HEISS, A.A., HOPPENRATH, M., JAMES, T.Y., KARNKOWSKA, A., KARPOV, S., KIM, E., KOLISKO, M., KUDRYAVTSEV, A., LAHR, D.J.G., LARA, E., LE GALL, L., LYNN, D.H., MANN, D.G., MASSANA, R., MITCHELL, E.A.D., MORROW, C., PARK, J.S., PAWLOWSKI, J.W., POWELL, M.J., RICHTER, D.J., RUECKERT, S., SHADWICK, L., SHIMANO, S., SPIEGEL, F.W., TORRUELLA, G., YOUSSEF, N., ZLATOGURSKY, V. and ZHANG, Q., 2019. Revision to the classification, nomenclature, and diversity of Eukaryotes. The Journal of Eukaryotic Microbiology, vol. 66, no. 1, pp. 4-119. http://dx.doi.org/10.1111/jeu.12691. PMid:30257078.

AL-QASSAB, S., LEE, W.J., MURRAY, S., SIMPSON, A.G.B. and PATTERSON, D.J., 2002. Flagellates from stromatolites and surrounding sediments in Shark Bay, Western Australia. Acta Protozoologica, vol. 41, no. 2, pp. 91-144.

ARAÚJO, S.C., FISCHER, E.A. and SAZIMA, M., 2004. A flora de bromélias na região do estuário do Rio verde. In: O.A.M. MARQUES and W. DULEBA, eds. Ambiente, flora e fauna da Estação Ecológica da Juréia-Itatins. Ribeirão Preto: Holos Editora, pp.162-171.

ARNDT, H., DIETRICH, D., AUER, B., CLEVEN, E.J., GRÄFENHAN, T., WEITERE, M. and MYLNIKOV, A.P., 2000. Functional diversity of heterotrophic flagellates in aquatic ecosystems. In: B. S. C. LEADBEATER and J.C. GREEN, eds. The Flagellates Unity, Diversity and Evolution. London: Taylor and Francis, pp. 240-268.

BERNINGER, U.G., WICKHAM, S.A. and FINLAY, B.J., 1993. Trophic coupling within the microbial food web: a study with fine temporal resolution in a eutrophic freshwater ecosystem. Freshwater Biology, vol. 30, no. 1, pp. 419-432. http://dx.doi. org/10.1111/j.1365-2427.1993.tb00825.x.

BIYU, S., 2000. Planktonic protozooplankton (ciliates, heliozoans and testaceans) in two shallow mesotrophic lakes in China - a comparative study between a macrophyte-dominated lake (Biandantang) and an algal lake (Houhu). Hydrobiologia, vol. 434, no. 1, pp. 151-163. http://dx.doi.org/10.1023/A:1004060722281.

BUOSI, P.R.B., UTZ, L.R.P., MEIRA, B.R., SILVA, B.T.S., LANSAC-TÔHA, F.M., LANSAC-TÔHA, F.A. and VELHO, L.F.M., 2014. Rainfall influence on species composition of the ciliate community inhabiting bromeliad phytotelmata. Zoological Studies (Taipei, Taiwan), vol. 53, no. 1, pp. 32. http://dx.doi. org/10.1186/s40555-014-0032-4.

BURNS, C.W. and SCHALLENBERG, M., 2001. Calanoid copepods versus cladocerans: consumer effects on protozoa in lakes of different trophic status. Limnology and Oceanography, vol. 46, no. 6, pp. 1558-1565. http://dx.doi.org/10.4319/lo.2001.46.6.1558.
CAMARGO, J.C. and VELHO, L.F.M., 2010. Composition and species richness of flagellate protozoa from environments associated to the Baía River (Mato Grosso do Sul State): influence of the hydrological period and the connectivity. Acta Scientiarum. Biological Sciences, vol. 32, no. 4, pp. 349-356. http://dx.doi. org/10.4025/actascibiolsci.v32i4.6307.

CASTRO, A.A.J. and BICUDO, C.E.M., 2007. Cryptophyceae. In: C.E.M. BICUDO, eds. Flora ficológica do Estado de São Paulo. São Carlos: RiMa Editora, pp. 123-125.

CASTRO, A.A.J., BICUDO, C.E.M. and BICUDO, D.C., 1991. Criptógamos do Parque Estadual das Fontes do Ipiranga, São Paulo, SP. Algas 2: cryptophyceae. Hoehnea, vol. 18, no. 1, pp. 87-106.

CAVALLERO, L., LÓPEZ, D. and BARBERIS, I.M., 2009. Morphological variation of Aechmea disticantha (Bromeliaceae) in a Chaco forest: habitat and size-related effects. Plant Biology, vol. 11, no. 3, pp. 379-391. http://dx.doi.org/10.1111/j.14388677.2008.00123.x. PMid:19470109.

CÉSAR, D.E. and ABREU, P.C., 2001. Ecology of aquatic microorganisms in Southern Brazil: state of art. Oecologia Brasiliensis, vol. 9, no. 1, pp. 153-171. http://dx.doi.org/10.4257/ oeco.2001.0901.11

CORLISS, J.O., 2001. Have the Protozoa been overlooked? Bioscience, vol. 51, no. 6, pp. 424-425. http://dx.doi.org/10.1641/00063568(2001)051[0424:HTPBO]2.0.CO;2

CUNHA, A.M., 1913. Contribuição para o conhecimento da fauna de protozoários do Brasil. Memorias do Instituto Oswaldo Cruz, vol. 5, no. 2, pp. 101-122. http://dx.doi.org/10.1590/S007402761913000200001

DEBASTIANI, C., MEIRA, B.R., LANSAC-TOHA, F.M., VELHO, L.F.M. and LANSAC-TOHA, F.A., 2016. Protozoa ciliates ommunity structure in urban strams and their environmental use as indicators. Brazilian Journal of Biology $=$ Revista Brasileira de Biologia, vol. 76, no. 4, pp. 1043-1053. http://dx.doi. org/10.1590/1519-6984.08615. PMid:27191462.

DUARTE, G.S.C., ALVES, G.M., LANSAC-TÔHA, F.M., VELHO, L.F.M. and LANSAC-TÔHA, F.A., 2013. Flagellate protist abundance in phytotelmata of Aechmea distichantha Lem. (Bromeliaceae) in the upper Paraná River basin, Brazil. Acta Scientiarum. Biological Sciences, vol. 35, no. 4, pp. 491-498. http://dx.doi.org/10.4025/actascibiolsci.v35i4.17134.

EKEBOM, J., PATTERSON, D.J. and VØRS, N., 1996. Heterotrophic flagellates from coral reef sediments, (Great Barrier Reef, Australia). Archiv fur Protistenkunde, vol. 146, no. 4, pp. 251-272. http://dx.doi.org/10.1016/S0003-9365(96)80013-3.

EKELUND, F. and PATTERSON, D.J., 1997. Some flagellates from a cultivated garden soil in Australia. Archiv fur Protistenkunde, vol. 148, no. 4, pp. 461-478. http://dx.doi.org/10.1016/S00039365(97)80022-X

FENCHEL, T., 1982. Ecology of heterotrophic flagellates. IV. Quantitative occurrence and importance as bacterial consumers. Marine Ecology Progress Series, vol. 9, no. 1, pp. 35-42. http:// dx.doi.org/10.3354/meps009035.

FERNANDES, R., AGOSTINHO, A.A., FERREIRA, E.A., PAVANELLI, C.S., SUZUKI, H.I., LIMA, D.P. and GOMES, L.C., 2009. Effects of the hydrological regime on the ichthyofaunal of riverine environments of the Upper Paraná River floodplain. Brazilian Journal of Biology $=$ Revista Brasileira de Biologia, vol. 69, no. 2, (suppl.), pp. 669-680. http://dx.doi.org/10.1590/ S1519-69842009000300021. PMid:19738973. 
GASOL, J.M., SIMONS, A.M. and KALFF, J., 1995. Patterns in the top-down versus bottom-up regulation of heterotrophic nanoflagellates in temperate lakes. Journal of Plankton Research, vol. 17, no. 10, pp. 1879-1903. http://dx.doi.org/10.1093/ plankt/17.10.1879.

GLÜKSMAN, E., SNELL, E.A. and CAVALIER-SMITH, T., 2013. Phylogeny and evolution of Planomonadida (Sulcozoa): eight new species and new genera Fabomonas and Nutomonas. European Journal of Protistology, vol. 49, no. 3, pp. 179-200. http://dx.doi.org/10.1016/j.ejop.2012.08.007. PMid:23369787.

GOMES, E.A.T. and GODINHO, M.J.L., 2003. Structure of the protozooplankton community in a tropical shallow and eutrophic lake in Brazil. Paris. Acta Oecologica, vol. 24, pp. 153-161. http:// dx.doi.org/10.1016/S1146-609X(03)00039-0.

GREENEY, H.F., 2001. The insects of plant-held waters: a review and bibliography. Journal of Tropical Ecology, vol. 17, no. 2, pp. 241-260. http://dx.doi.org/10.1017/S026646740100116X.

HEISS, A.A., WALKER, G. and SIMPSON, A.G., 2011. The ultrastructure of Ancyromonas, a eukaryote without supergroup affinities. Protistology, vol. 162, no. 3, pp. 373-393. http://dx.doi. org/10.1016/j.protis.2010.08.004. PMid:21420357.

JEUCK, A. and ARNDT, H., 2013. A short guide to common heterotrophic flagellates of freshwater habitats based on the morphology of living organisms. Protistology, vol. 164, no. 6, pp. 842-860. http://dx.doi.org/10.1016/j.protis.2013.08.003. PMid:24239731.

JUNCÁ, F.A. and BORGES, C.L.S., 2002. Fauna associada a bromélias terrícolas da Serra da Jibóia, Bahia. Sitientibus. Série Ciências Biológicas, vol. 2, pp. 73-81.

KITCHING, R.L., 2001. Food webs in phytotelmata: "bottom-up" and "top-down" explanations for community structure. Annual Review of Entomology, vol. 46, no. 1, pp. 729-760. http://dx.doi. org/10.1146/annurev.ento.46.1.729. PMid:11112185.

KITCHING, R.L., 2004. Food Webs and Container Habitats: the natural history and ecology of Phytotelmata. Cambridge: Cambridge University Press.

LANSAC-TOHA, F.M., MEIRA, B.R., SEGOVIA, B.T., LANSAC-TOHA, F.A. and VELHO, L.F.M., 2016. Hydrological connectivity determining metacommunity structure on planktonic heterotrophic flagellates. Hydrobiologia, vol. 781, no. 1, pp. 8194. http://dx.doi.org/10.1007/s10750-016-2824-5.

LARSEN, J. and PATTERSON, D.J., 1990. Some flagellates (Protist) from tropical marine sediments. Journal of Natural History, vol. 24, no. 1, pp. 801-937. http://dx.doi.org/10.1080/00222939000770571.

LEE, W.J., SIMPSON, A.G.B. and PATTERSON, D.J., 2005. Free-living heterotrophic flagellates from freshwater sites in Tasmania (Australia), a field survey. Acta Protozoologica, vol. 44, no. 8, pp. 321-350.

MAGUIRE JUNIOR, B., 1971. Phytotelmata: biota and community structure determination in plant-held waters. Annual Review of Ecology Evolution and Systematics, vol. 2, no. 1, pp. 439-464. http://dx.doi.org/10.1146/annurev.es.02.110171.002255.

MESTRE, L.A.M., ARANHA, J.M.R. and ESPER, M.L.P., 2001. Macroinvertebrates fauna associted to the bromeliad. Vriesea inflata the Atlantic forest (Paraná State, Southern Brazil). Brazilian Archives of Biology and Technology, vol. 44, no. 1, pp. 89-94. http://dx.doi.org/10.1590/S1516-89132001000100012.
MOREIRA, D., LÓPEZ-GARCIA, P. and VICKERMAN, K., 2004. An updated view of kinetoplastid phylogeny using environmental sequences and a closer out group: proposal for a new classification of the class Kinetoplastea. International Journal of Systematic and Evolutionary Microbiology, vol. 54, no. 5, pp. 1861-1875. http://dx.doi.org/10.1099/ijs.0.63081-0. PMid: 15388756

OMENA, P.M. and ROMERO, G.Q., 2008. Fine-scale microhabitat selection in a bromeliad-dwelling jumping spider (Salticidae). Biological Journal of the Linnean Society. Linnean Society of London, vol. 94, no. 4, pp. 653-662. http://dx.doi. org/10.1111/j.1095-8312.2008.01039.x.

PATTERSON, D.J. and SIMPSON, A.G.B., 1996. Heterotrophic flagellates from coastal marine and hypersaline sediments in Western Australia. European Journal of Protistology, vol. 32, no. 1, pp. 1-24. http://dx.doi.org/10.1016/S0932-4739(96)80003-4.

PAULETO, G.M., VELHO, L.F.M., BUOSI, P.R.B., BRÃO, A.I.S., LANSAC-TOHA, F.A. and BONECKER, C.C., 2009. Spatial and temporal patterns of ciliate species composition (Protozoa: Ciliophora) in the plankton of the Upper Paraná River floodplain. Brazilian Journal of Biology $=$ Revista Brasileira de Biologia, vol. 69, no. 2, (suppl.), pp. 517-527. http://dx.doi.org/10.1590/ S1519-69842009000300007. PMid:19738959.

PERNTHALER, J., ŠIMEK, K., SATTLER, B., SCHWARZENBACHER, A., BOBKOVA, J. and PSENNER, R., 1996. Short-term changes of protozoan control on autotrophic picoplankton in an oligomesotrophic lake. Journal of Plankton Research, vol. 18, no. 1, pp. 443-462. http://dx.doi.org/10.1093/ plankt/18.3.443.

PICKEN, L.E.R., 1941. On the bicoecidae: a family of colourless flagellates. Philosophical Transactions of the Royal Society of London. Series B, Biological Sciences, vol. 575, no. 579, pp. 451-473. http://dx.doi.org/10.1098/rstb.1941.0002.

PREISIG, H.R. and HIBBERD, D.J., 1982. Ultrastructure and taxonomy of Pharaphysomonas (Chrysophyceae) and related genera. Nord Journal of Biology, vol. 2, no. 4, pp. 695-723.

RICHARDSON, B.A., 1999. The bromeliad microcosm and the assessment of diversity in a neotropical forest. Biotropica, vol. 31, no. 2, pp. 321-336. http://dx.doi.org/10.1111/j.1744-7429.1999. tb00144.x.

ROMERO, G.Q., MAZZAFERA, P., VASCONCELLOS-NETO, J. and TRIVELIN, P.C.O., 2006. Bromeliad-living spiders improve host plant nutrition and growth. Ecology, vol. 87, no. 4, pp. 803808. http://dx.doi.org/10.1890/0012-9658(2006)87[803:BSIHPN ]2.0.CO;2. PMid:16676522.

SANDERS, R.W., 1991. Trophic strategies among heterotrophic flagellates. In: J. Patterson and J. Larsen, eds. The biology of freeliving heterotrophic flagellates. Oxford: Clarendon Press, pp. 21-38.

SCHMIDT-HALEWICZ, S.E., 1994. Composition and seasonal changes of the heterotrophic plankton community in a small oligotrophic reservoir. Archiv für Hydrobiologie, vol. 40, no. 1, pp. 197-207.

SCHROECKH, S., LEE, W.J. and PATTERSON, D.J., 2003. Free-living heterotrophic flagellates from freshwater sites in mainland Australia. Hydrobiologia, vol. 494, no. 3, pp. 131-166. http://dx.doi.org/10.1023/A:1025457801420.

SIMEK, K., ARMENGOL, A.J., COMERMA, M., GARCIA, J.C., CHRZANOWSKI, T.H., KOJECKÁ, P., MACEK, M., NEDOMA, J. and STRASKRABOVÁ, V., 1999. Impacts of prostitan grazing on bacterial dynamics and composition in reservoirs 
of different trophy. In: J.G. TUNDISI and M. STRASKRABA, eds. Theoretical reservoir ecology and its application. São Carlos: International Institute of Ecology, pp. 267-282.

SMITH, L.B. and DOWNS, R.J., 1979. Bromelioideae (Bromeliaceae). Flora Neotropica, vol. 14, no. 3, pp. 1493-2142.

SOUZAFILHO, E.E. and STEVAUX, J.C., 2004. Geomorphology of the Paraná River Floodplain in the reach between the Paranapanema and Ivaí Rivers. In:A.A. AGOSTINHO, L. RODRIGUES, L.C. GOMES, S.M. THOMAZ and L.E. MIRANDA, eds. Structure and functioning of the Paraná River and its flooplain. Maringá: Eduem, pp. 9-13.

SRIVASTAVA, D.S., KOLASA, J., BENGTSSON, J., GONZALEZ, A., LAWLER, S.P., MILLER, T.E., MUNGUIA, P., ROMANUK, T., SCHNEIDER, D.C. and TRZCINSKI, M.K., 2004. Are natural microcosms useful model systems for ecology? Trends in Ecology \& Evolution, vol. 19, no. 7, pp. 379-384. http:// dx.doi.org/10.1016/j.tree.2004.04.010. PMid:16701289.

TAKEDA, A.M., LANSAC-TÔHA, F.A. and AGOSTINHO, A.A., 2002. Estudos ecológicos de longa duração: reservatório do Itaipu e planície de inundação do alto rio Paraná (Brasil). Cadernos da Biodiversidade, vol. 3, no. 2, pp. 51-63.
TIKHONENKOV, V.D. and MAZEI, A.Y., 2007. Heterotrophic flagellates from freshwater biotopes of Matveev and Dolgii Islands (the Pechora Sea). Protistology, vol. 4, no. 1, pp. 327-337.

TONG, S.M., NYGAARD, K., BERNARD, C., VØRS, N. and PATTERSON, D.J., 1998. Heterotrophic flagellates from the water column in Port Jackson, Sydney, Australia. European Journal of Protistology, vol. 34, no. 2, pp. 162-19. http://dx.doi. org/10.1016/S0932-4739(98)80027-8.

TONG, S.M., VØRS, N. and PATTERSON, D.J., 1997. Heterotrophic flagellates, centrohelid heliozoa and filose amoebae from marine and freshwater sites in the Antarctic. Polar Biology, vol. 18, no. 1, pp. 91-106. http://dx.doi.org/10.1007/s003000050163.

WEISSE, T., 1991. The annual cycle of heterotrophic freshwater nanoflagellates: role of botton-up versus top-down control. Journal of Plankton Research, vol. 13, no. 1, pp. 167-185. http://dx.doi. org/10.1093/plankt/13.1.167.

WILLIAMS, D.D., 2006. The biology of temporary waters. Oxford: Oxford University Press. 